\title{
STOCK MARKET REACTIONS TO MERGERS ANNOUNCEMENT: AN EMPIRICAL STUDY ON RECENT 2020'S INDIAN MEGA BANK MERGER
}

\author{
Rajashree Upadhyay \\ Research Scholar, Department of Commerce, Kazi Nazrul University, Asansol Paschim Bardhaman, \\ West Bengal, Pin - 713340 \\ Dr. Mahesh Kumar Kurmi * \\ Assistant Professor, Department of Commerce, Kazi Nazrul University, Asansol Paschim Bardhaman, \\ West Bengal, Pin - 713340
}

Article DOI: $\underline{\text { https://doi.org/10.36713/epra4948 }}$

\begin{abstract}
Mergers and acquisitions are being used as strategic tools by Indian Corporate houses especially by Indian banking sector during last three decades of post liberalization era. Banking Sector in India has witnessed a mega merger of 10 Indian public banks into four big banks with effect from 1st April 2020 which definitely attract attention of different stakeholder who are interested to know whether these tie up events are really helpful for improving present scenario of banking industry as well as economic condition of the country in long run. But our concern in this study is to figure out the changes that occurred in shareholders wealth of the acquiring firm in short run around the announcement of merger event by detecting the responses of the share prices of acquiring bank through the procedure of event study methodology. For this study, company specific and market specific secondary data have been collected from the official website of National Stock Exchange as these companies are actively traded on said exchange. To accomplish the objective of this study we relied on figure of Average Abnormal Returns (AAR) and Cumulative Average Abnormal Returns (CAAR) for an event window of 41 days from day -20 to day +20 . Return values have been statistically tested through cross sectional $t$-test. The notable finding of the research is that an under-reaction of market is observed before the announcement but the moment the announcement information becomes effective, investors start reacting from day +2 and the stock price jumps up, providing positive AARs to the investors. But after the positive respond to the merger information, finally investors have under-reacted to the event. CAARs figures also indicate the positive pattern of returns in the beginning of the event window but rapidly it becomes negative from day -16 to the last day of window that might be due to pandemic situation running throughout the world.
\end{abstract}

KEYWORDS: Merger \& Acquisition, Event Study, Stock Return, Abnormal Return, Banking Sector

\section{INTRODUCTION}

Since from very early period the activities of merger events are begun and these tie up deals are done sometimes by will of the respective organizations or sometimes by force of law. Merger is nothing but fusion of two or more corporations. In simple terms 'Merger' means the act of joining two or more separate corporate bodies in a single one. The main purposes for these kinds of consolidation events are to solve the contemporary status quo of the business concern with strengthening its market position. By adopting such kind of unification decisions, organizations want to enjoy the ' $1+1=3$ ' type of synergy benefits. In Indian context almost from 1903 the historical perspective 


\section{EPRA International Journal of Research and Development (IJRD)}

Volume: 5 | Issue: 8 | August 2020

- Peer Reviewed Journal

revealed that merger decisions which were taken in first phase, later on proven unsuccessful. But thereafter continuous rapid changing economic environment are pointed out the necessities of merger activities as a tool of survival. This tie up events not only affects the respective corporate sectors but also to the economy of the country.

Banking sector which is the most remarkable pillar for any country's economic structure, has also experienced many tie up events in both domestic \& foreign banks with cross border merger deals. Banking sector is the backbone of overall monetized economic system and any minor to major changes happened on it have direct impact on country's economic system. Mainly for globalization, Indian banking industry faces keen competition from various foreign banks. On the other hand, incline trends of Non-Performing Assets (NPA) in Indian banking sectors have opened up the path of consolidation events. So, sometimes for long term survival with strengthening market position and sometimes for market expansion with enjoying synergy benefits by covering the loopholes of the weaker banks, Indian banks have preferred the path of merger deal.

With the object to augment the present economic condition, a mega alliance of 10 Indian public banks to 4 large entities, had been publicized on August 30, 2019 by Niramala Sitharaman, Finance Minister of India. Almost from December 2019 very promptly day by day a pandemic situation creates in the world and India also face the adverse state of this pandemic start from March 2020. To put control over these dangerous covid-19 phase several lock down decision have been taken by the government at various levels in all over the country and within this lock down period, from April 1, 2020 the declaration of mega tie up event of ten Indian public bank into four big banks have been came into effect. In this mega bank merger, Oriental Bank of Commerce and United Bank of India have been merged with Punjab National Bank, Canara Bank acquired Syndicate Bank, Andra Bank and Corporation Bank have been subsumed with Union Bank of Indian Bank and Alllahabad Bank have been merged with Indian Bank. Where the whole India not only discomfort for pandemic situation but also suffering for several lock down stages which arisen huge financial problems, in this vital deteriorated Indian economic condition it definitely attract attention of many peoples that these banks tie up events are really helpful for improving economic condition in long run or not. But our concern in this study is to measure the changes that occurred in shareholders wealth of the acquiring firm in short run around the announcement of merger event by identifying the responses of the share prices of acquiring bank.

However, the structure of this paper is as follows: Part 2 takes up the summary of prior studies in form of literature review accessible in this pitch, Part 3 highlights the objectives of the study, Part 4 makes available a look over the hypothesis, Part 5 depicts the methodology followed, Part 6 puts focus on the findings and its interpretation and finally, last part is concerned with the conclusion of the research.

\section{REVIEW OF EXISTING LITERATURE}

A survey of the available literature in this area reports us that a good number of empirical studies have been conducted so far to assess the bearing of tie up announcement on the short term performance of acquiring banks but the results are quite mix. A number of studies have advocated that the shareholders' value of the acquiring firms have been amplified due to tie up event in short run whereas few other studies have reported that the short term performance have adversely affected just before and after the merger announcement in short run. However, a quick and significant scan of the accessible studies on this vital issue looks appropriate before stepping towards this empirical study.

Kalaichelvan (2011) presented his views on the behavior of security prices in Indian banking sector for the announcement of tie up decision through his research study titled "Efficacy of merger and acquisition in Indian banking industry". Researcher mainly considered 8 acquisition event in this study viz., tie up between Bank of Baroda with Bareilly Corporation Bank Ltd, BOB with Banaras State Bank Ltd, Oriental Bank of Commerce with Punjab Co - op \& Bari Doab Bank Ltd, OBC with Global Trust Bank Ltd, Punjab National Bank with Nedungadi Bank, State Bank of India with Kashinath Seth Bank, HDFC Bank Ltd with Times Bank Ltd and ICICI Bank with Bank of Madura Ltd. The relevant information associated with market index \& security index are mainly gathered from CMIE secondary database. Basically this study has investigated the changes that occurred in shareholders wealth due to unification decision with the help of abnormal return \& cumulative abnormal returns by adopting Market model \& Market adjusted model. After the analysis of the taken data, it is found that in BOB with Bareilly Corporation Bank Ltd merger deal, an increased shareholders wealth noticed which means this tie up decision reflected positive impact of 


\section{EPRA International Journal of Research and Development (IJRD)}

Volume: 5 | Issue: 8 | August 2020

- Peer Reviewed Journal

consolidation on security prices of unified bank as per event study approach. But BOB with Banaras State Bank Ltd tie up case, it represented adverse response on security prices of the merged bank which resulted declined shareholders wealth. On the other hand, OBC with Punjab Co-op \& Bari Doab Bank Ltd unification deal, it showed unchanged behavior of stock prices which signifies that this tie up event failed to create any notable movement in security prices and for that reason mentionable changes in shareholders wealth is not observed. While in the case of OBC with Global Trust Bank Ltd take over deal declined shareholders wealth with negative reaction of market on security prices observed. Whereas reduction of wealth in terms of market risk \& improved wealth as per market return is depicted in Punjab National Bank with Nedungadi Bank Ltd tie up case. An inclined with positive wealth of shareholders is found in State Bank of India merger deal. Unification between HDFC Bank with Times Bank Ltd expressed favorable changes in shareholders wealth, while ICICI tie up decision showed on an average changes in shareholders wealth.

Narwal et al. (2013) try to find out the impact of tie up announcement of both forced \& voluntary merger on the stock return of merging banks through their article "Stock Market Reactions to Mergers Announcement : A Study of Voluntary and Compulsory Mergers in Indian Banking Sector". This study was based on seven compulsory \& six voluntary consolidation deal for the period from 2000 to 2012 . The relevant data are extracted from NSE's official website and Event study methodology is used for analysis of data. Here 21 days event window is used for interpretation and the ultimate conclusion has been drawn by applying t-test statistical tool. The examined result exposed that both the forced \& voluntary tie up cases showed negative returns and forced merger event depicted more adverse return than voluntary event in after announcement. So, there is no significant enhancement noticed from pre consolidation phase to post consolidation phase. According to this study, at initial level, the market accept this tie up announcement in a favorable way but later on returns turn out negative. As a whole it can be concluded that the selected merger event failed to achieve improved stock returns as the reactions of the market are unfavorable.

Samontaray et al. (2013) conducted a study titled "Merger and Acquisition in Indian Banking Industry: An Event Study Approach" to get a critical understanding over the fact whether bank mergers really create value for their shareholders or not. To achieve their goal, researchers have used three portfolios of banking company's securities viz., Nationalized banks, Private banks \& Combination of all securities, for the period of 1993-2010 as a sample data and applied Event study methodology to arrive their conclusion. They have also tried their level best to explore the effects of consolidation on shareholders return of the acquiring banks. For supporting their hypothesis, researchers have used some suitable statistical test such as Simple T -test, Paired Sample T test \& Wilcoxon sign rank test. Their result concluded that for both the private \& public banks, the selected tie up events is succeeding to generate Average Abnormal returns for the acquirers. CAAR's are created $3.56 \%$ \& $10.45 \%$ respectively for both public \& private banks individually. The result of simple $\mathrm{T}$-test signified that there are some abnormal returns to all investors but private sector bank investors are enjoying more than that of public sector banks' investors. The result of paired sample $\mathrm{T}$-test \& Wilcoxon sign rank test also suggested that some abnormal returns are created for all bank shareholders. From overall result, it can be concluded that the acquirer company's shareholders are gaining abnormal returns on an average of $0.62 \%$ at least in short run but in the long run there is no significant changes in shareholders' value is observed due to merger event.

Shah et al. (2013) conducted a study titled "Bank Mergers and Shareholders Value Creation in India" to understand the impact of Indian banks tie up decision on the stock price behaviour for both acquirer as well as the target shareholders wealth. The study was based on a sample of 17 ties up announcements both by public \& private sector banks and researchers have drawn the required data from the official website of BSE \& the Centre for Monitoring Indian Economy (CMIE) Prowess. They have analyzed the data by using Event study methodology to ascertain the changes occurred in the stock price. For this study, the researchers mainly used OLS Market Model and Constant Market Model for testing of abnormal returns on stock price in prior \& after the announcement of consolidation event for both the acquired \& acquiring banking companies. The study indicates that the shareholders of target firms enjoyed the unification related wealth generation in most of the times; on the other hand, public \& private bidder banks failed to generate any positive or negative abnormal returns when they are analyzed independently. The researchers found that no relationship is observed between the bidder of public \& private sector bank's shareholders 


\section{SJIF Impact Factor: 7.001| ISI I.F.Value:1.241| Journal DOI: 10.36713/epra2016 ISSN: 2455-7838(Online) EPRA International Journal of Research and Development (IJRD) Volume: 5 | Issue: 8 | August 2020

wealth with consolidation announcement. This study also shows that the bidding banks do not suffer any loss which implied that investment in M\&A are not risky for shareholders of those banks whereas a significant abnormal return is enjoyed by the shareholders of the target banks.

Patel et al. (2016) attempted to investigate stock risk return performance of merged banks during pre tie up $\&$ post tie up period in their research article "Mergers and Acquisitions : A Pre-Post Risk Return Analysis for the Indian Banking Sector". Researchers mainly considered six unified banks as a sample of this investigation which are merged between the period from 2004 to 2010. These selected banks are Oriental Bank of Commerce, Federal Bank, IDBI bank, Indian Overseas Bank, HDFC bank and ICICI bank. All the necessiate data are collected from secondary sources like Yahoo finance, money control and through reports of various banks. Data are analysed with the help of Event study methodology. After detailed assessment, researchers have found that HDFC bank have highest improved unsystematic risk and IDBI bank have maximum declined unsystematic risk. IDBI also have lowest systematic risk where as Federal Bank had maximum systematic risk. Overall mixed stock risk return is observed, as two banks revealed positive stock return, three banks have negative stock return and one sample bank has average return. This study has concluded that the selected merged banks had not given much satisfactory report. Researchers further suggested that before taking any merger decision it is important to analyse the financial performance of both the target \& bidder banks for enjoying the synergy benefits of tie up event.

Kumar et al. (2016) attempted a study titled "Wealth creation in the largest banking mergers: An empirical analysis" to measure the changes that occurred in stock wealth behavior due to tie up announcement of the merging banks. The researchers have considered a sample of 32 acquirer and 9 target banks in this study for which merging events are done from the period of 1997 to 2013. They have applied Event study methodology and investigated the data with the help of cumulative abnormal return analysis. The resulted outcome shows that the target banks are performed well for enhancing their abnormal returns \& cumulative abnormal returns. The announcement become beneficial for the target banks as these announcements creates significant value for them. However, acquirer banks failed to generate wealth as it depicted adverse cumulative abnormal returns due to tie up announcement which indicated negative impact of merger announcement on the stock wealth. So, as per this study, it can be concluded that only target banks have enjoyed the synergy benefits of merger in terms of wealth creation on account of merger.

Yadav (2017) attempted to examine the relationship between the merger announcement and the existence of favorable abnormal returns for shares of banking firms in his research study, "Impact of Mergers and Acquisitions on the Performance of the Indian Bank's Share Price : An Event Study Approach ". The study covered mainly four major ties up events in banking sector i.e. Kotak Mahindra Bank with ING Vyasa Bank, ICICI Bank with Bank of Rajasthan Ltd, HDFC Bank with Centurion Bank of Punjab and HDFC Bank with Times Bank Ltd; and data has been drawn from the website of National Stock Exchange \& are analyzed through Event Study Approach. In this research, abnormal return was the main function and these abnormal returns were different for each window \& each acquisition deal. The result of this study showed that in case of consolidation between Kotak Bank \& ING Vyasa Bank; Kotak Bank's shareholder's abnormal return is $14.30 \%$ \& $13.58 \%$ during event window based on estimation window and after the effective day of the acquisition Kotak Bank's Abnormal Return went down to $3.10 \%$ \& $2.94 \%$ respectively. It can be concluded that, this acquisition create profit for shareholders during event window period and for that reason if someone wants to get abnormal returns on the shares, the investor must purchase Kotak shares before the announcement date. In case of ICICI Bank with Bank of Rajasthan, unification deal revealed that after effective day of acquisition ICICI's abnormal return raised up to $1.75 \%$ \& $1.24 \%$ from abnormal return $-5.22 \%$ \& $-5.15 \%$ during event window based on estimation window. So, it can be resulted that the banks share price hiked after effective day of acquisition \& shareholders got benefit but it is very less in comparison to Kotak bank's shareholders. The analyzed report of tie up between HDFC Bank with Centurion Bank of Punjab indicated that HDFC's shareholders received abnormal return during post event window, but it was hypothetical return because actual return is in negative form, so shareholders enjoyed the benefit for little time. The investigated findings for consolidation of HDFC Bank with Times Bank Ltd expressed that after effective day of acquisition HDFC'S abnormal return increased after up-to $49.82 \% \& 50.25 \%$ as comparison with event window period's abnormal return which is $13.75 \%$ \& 


\section{EPRA International Journal of Research and Development (IJRD)}

$16.24 \%$. So, it can be concluded depending on the research study that HDFC'S shareholders received adequate expected returns in terms of share price. The overall result showed that the bank merger create value for shareholders to some extent.

Anand et al. (2018) gave the views on changes in shareholders wealth due to unification event in their research investigation titled "Impact of Merger Announcements on Shareholders Wealth: Evidence from Indian Private Sector Banks". The researchers mainly considered five merger deals, namely; merger between HDFC Bank with Times Bank, ICICI Bank with Bank of Madura, ICICI Bank with ICICI Ltd, Oriental Bank of Commerce with Global Trust Bank and Centurion Bank with Bank of Punjab by covering from 1999 to 2005. The relevant data are collected from various secondary sources and data have been analyzed by means of Event Study methodology. The interpreted result showed that the bidder banks average cumulative abnormal return reflected positive significant abnormal returns. Same as in case of target banks, favorable significant abnormal returns have also been noticed. Except Oriental Bank of Commerce \& Global Trust Bank all other banks' analyzed report has expressed positive \& significant increased shareholder value. The overall results concluded that there is significant positive \& enhanced shareholder wealth observed in case of both bidder banks \& target banks after tie up.

Kalsie et al. (2018) reviewed the impact of tie up announcement on stock prices for both the acquiring bank \& target bank through their research article "Analysis of Merger and Acquisition Deals of Major Indian Banks: An Event Based Study". The major six consolidation deal, namely; merger between OBC with Global Trust Bank, IDBI with IDBI bank, IDBI with United Western Bank, HDFC Bank with Centurion Bank of Punjab, ICICI Bank with Bank of Rajasthan \& Kotak Mahindra Bank with ING Vysya Bank considered in this study that happened during the period from 2004 to 2014 . This research study analyzed stock movement of 10 days pre acquisition announcement date \& 10 days after acquisition announcement date to measure the effect of merger decision on stock price movement by adopting Market model \& Market Adjusted model and also used regression analysis to identify the relation between market returns \& the stocks actual returns. The findings of this study revealed that in 10 days prior unification announcement, some abnormal returns observed but later on after the announcement of consolidation events these abnormal returns especially after the 4 days of announcement gradually vanished. Average abnormal returns found exceptional during 10 days pre take over $\& 6$ days post take over period. While only 10 days prior the announcement of tie up, significant cumulative average abnormal returns is noticed. This study indicates that in case of forced merger, around the day of declaration of tie up decision both the acquiring \& target bank lost value of its entities. So overall, this study depicted that all the merging entities failed to enjoyed synergy benefit of the consolidation announcement but though this interpretation is based on short term analysis of stock price movement hence this article may not gave us accurate result for long term period.

Kumara et al (2019) in their research work "A Study on the Impact of Pre and Post Bank Merger Announcement on Stock Price Movement" focused to determine the stock price movement for the declaration of bank merger affair and its impact. Both Public sector \& Private sector merger deal from 2010 to 2018 are considered here and within this period major four merger cases ( i.e. tie up between ICICI Bank with Bank of Rajasthan, Kotak Mahindra Bank with ING Vysya Bank, SBI with its five associate banks and Bank of Baroda with Dena Bank \& Vijaya Bank) are taken for this investigation. All necessary data are collected from RBI press release, NSE SENSEX etc. for 7 days prior event \& 7 days after event period and declaration date of merger is pointed as event date. In this article, drawn data are analyzed by adopting Event Study methodology to find out significant investigated result. The interpreted report in ICICI Bank consolidation case, revealed that on the day of announcement positive co-efficient observed and 7 days prior $\& 7$ days after i.e. on pre $\&$ post tie up event period, on an average enhanced stock price noticed but at the time of hypothesis testing, results showed no significant changes on stock price during prior \& after merger event. In case of Kotak Mahindra Bank, the outcome of investigation reflected that in the pre \& post consolidation event, on an average $2 \%$ increased trend on stock price observed. But later on hypothesis examined report showed that no significant changes observed on stock price as a result of merger announcement event. SBI \& its 5 associate banks also failed to reflect any significant differences on stock price of such acquiring bank in both the pre tie up event $\&$ post tie up event period. Same as, there is no remarkable changes marked on stock price movement 


\section{EPRA International Journal of Research and Development (IJRD)}

of Bank of Baroda merger deal in pre-merger event period and post-merger event period of that acquiring bank. As a whole, this research study concluded that there is not so much effect of consolidation decision on stock price of acquiring banks.

Chaitra et al. (2019) reviewed the impact of consolidation on stock price movement of Indian banking sector for a period 1/1/2004 to $7 / 3 / 2019$ through their research investigation titled "An Analysis of pre and post-merger of Indian Banks : An Event Analysis approach". The researchers included both public banks \& private banks merger deal, such as; merger between State Bank of India with State Bank of Indore, ICICI Bank Ltd with Bank of Rajasthan Ltd, IDBI bank Ltd with IDBI Home Finance Ltd, Indian Bank with and Fund Management Ltd, HDFC Bank Ltd with JM Financial Stock Soars, IDFC Bank Ltd with Capital First Securities Ltd, Capital First Home Finance Pvt Ltd \& Capital First Ltd and Kotak Mahindra Bank with ING Vysya Bank Ltd. The relevant data are taken from many secondary sources, like banks annual reports, BSE website, other web based data source etc. Researchers have analyzed the collected data by applying Event Study approach. The analyzed result of State Bank of India \& ICICI bank depicted significant differences on stock price movement due to tie up event, while IDBI revealed insignificant difference with null impact of consolidation on stock price. Indian Bank \& HDFC Bank expressed that there are significant changes observed on stock price movement for tie up event. Same as Kotak Mahindra Bank had measurable impact of tie up on stock price of these merged banks with changed abnormal \& cumulative return. Overall this investigation demonstrated essentially an improved performance on stock price behavior of merged banks in after consolidated period.

In-depth review of the existing literatures clearly shows that literature base relating to the assessment of short term performance of acquiring firm around the tie up event is very strong in India. But, there is hardly any study which has attempted to examine the issue of short term performance of acquiring firm around the tie up event of mega merger of Indian ten public banks into four big public banks effective on $1^{\text {st }}$ April 2020. Thus, a modest attempt has been made to bridge the gap of the existing literature in context of merger of Indian banking sector.

\section{OBJECTIVES OF THE STUDY}

Following are the specific objectives of this study:

(a) To empirically investigate the extent of abnormal returns that might be earned by shareholders owing to the merger announcement.

(b) To examine empirically whether abnormal returns earned before announcement is significantly differ from abnormal returns earned after the merger announcement.

\section{HYPOTHESES OF THE STUDY}

To attain the above itemized objectives, the subsequent null hypotheses are formulated:

Hypothesis I: There is no significant impact of merger announcement on average abnormal return (AAR) and on cumulative average abnormal return (CAAR).

Rejection of the null hypothesis indicates a statistically significant impact of merger announcement on average abnormal return (AAR) and on cumulative average abnormal return (CAAR).

Hypothesis II: There is no significant difference between the abnormal returns earned before and after the merger announcement.

Rejection of the null hypothesis indicates a statistically significant difference between the abnormal returns earned before and after the merger announcement.

\section{DATABASE AND METHODOLOGY OF THE STUDY}

This research has been performed pertaining to mega merger of ten Indian public banks into four banks effective from $1^{\text {st }}$ April 2020. All the acquiring banks i.e., Punjab National Bank, Canara Bank, Union Bank of India and Indian Bank are traded on National Stock Exchange. The data analyzed in this research is basically secondary data that has been obtained from official website of acquiring bank and also from the website of National Stock Exchange (NSE).

To achieve first specific objective of the study and to test the research hypothesis I, event study approach has been applied in this study. Event study approach is normally castoff to scan the immediate valuation impacts of an unexpected announcement of corporate events such as declaration of dividend, buy back of share etc., by inspecting the early reactions of the share price that might appear just before and after the effective date of event. The corporate event defined 


\section{EPRA International Journal of Research and Development (IJRD)}

for our study is the event of mega merger in Indian banking sector.

Time line of event study is very crucial to account for the early responses of share prices accurately. Time line of an event study normally consists of three components- estimation window, event window and event date.

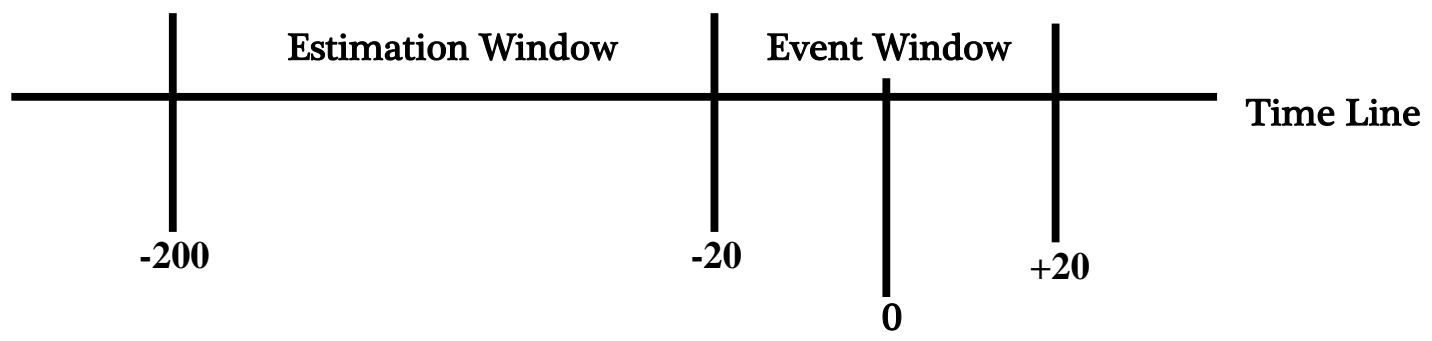

\section{Event Date}

For the present study, the estimation window is considered from the day -200 to the day -21 (180 trading days) in order to warrant that estimates of the normal return model are not affected by the returns expected around the event. The event window for this study is taken as -20 to +20 days which also include 0 day. Here, 0 day represents the date of event and -20 is the 20 days' period prior to the date of event, and +20 is the 20 days' period subsequent to the date of event.

The basic concern associated with the event study is to quantify the extent to which stock return behave abnormally within the event window of a specific event. These abnormal responses of share price due to an unexpected event can be interpreted feasibly through the concept of Abnormal Returns (ARs). Abnormal return is actually the difference between the actual return and the expected return. ARs are actually that unexplained part of actual return which arises due to some abnormal or unexpected event and that is not normally captured by the expected return model.

Actual returns of individual bank's stock have been computed by using following formula-

Where,

$$
\mathrm{R}_{\mathrm{jt}}=\ln \left(\frac{\mathrm{P}_{\mathrm{jt}}}{\mathrm{P}_{\mathrm{jt}-1}}\right)
$$

$R_{j t}=$ Return of jth stock at the time ' $t$ '

$P_{j t}=$ closing price of the jth stock at the time ' $t$ '

$\mathrm{P}_{\mathrm{jt}-1}=$ closing price of the jth stock at the time ' $\mathrm{t}-$ $1^{\prime}$

$\ln =$ natural $\log$ transformation

Market returns have been computed by using following formula-
Where,

$$
\mathrm{R}_{\mathrm{mt}}=\ln \left(\frac{\mathrm{P}_{\mathrm{mt}}}{\mathrm{P}_{\mathrm{mt}-1}}\right)
$$

$\mathrm{R}_{\mathrm{mt}}=$ Market Return at the time ' $\mathrm{t}$ ' $\quad \mathrm{P}_{\mathrm{mt}}=$ closing price of the market index at the time ' $t$ ' ;

$\mathrm{P}_{\mathrm{mt}-1}=$

closing price of the market index at the time ' $t-1$ '

$\ln =$ natural $\log$ transformation

Various statistical models are available to measure the expected return such as constant mean return model, market model, Capital Assets Pricing Model etc. The market model has been considered here to estimate the expected returns. It involves the regression of a stock's returns against a market index return. The market index -NSE NIFTY has been used here for regression. Market model as stated below has been used to estimates the expected return-

$R_{j t}=\alpha_{j}+\beta_{j} R_{m t}+\varepsilon_{j t}$

Where,

$\mathrm{R}_{\mathrm{jt}}=$ Expected Return on Security $\mathrm{j}$ at the time ' $\mathrm{t}$ '

$\alpha_{j}=$ alpha coefficient or constant term

$\beta_{\mathrm{j}}=$ Beta Coefficient

$\mathrm{R}_{\mathrm{mt}}=$ Rate of Return on Market Index at the time ' $\mathrm{t}$ ' $\varepsilon_{\mathrm{jt}}=$ error term, has an expected value of zero $\left[\mathrm{E}\left(\delta_{\mathrm{jt}}\right)=0\right]$ and a finite variance $\left[\operatorname{Var}\left(\delta_{\mathrm{jt}}\right)=\sigma_{\mathrm{ej}}^{2}\right]$

The parameters of the market model are estimated by using the time-series data from the estimation period that precedes each individual announcement. The parameters estimated are then used in the calculation of Abnormal Returns (ARs) for each day in the event window. The estimated parameters are then subtracted from actual returns in the event period to get any excess 


\section{EPRA International Journal of Research and Development (IJRD) \\ Volume: 5 | Issue: 8 | August 2020 \\ - Peer Reviewed Journal}

return, termed as Abnormal Return. The AR of firm $\mathrm{j}$ for the day $t\left(A_{\mathrm{jt}}\right)$ during the event window and estimation window period have been calculated as per the following equation:

$\mathrm{AR}_{\mathrm{jt}}=\mathrm{R}_{\mathrm{jt}}-\left(\widehat{\alpha}+\widehat{\beta} \mathrm{R}_{\mathrm{mt}}\right)$

In order to eliminate the idiosyncrasies in measurement of ARs due to particular stocks, Average Abnormal Returns (ARRs) have been considered here. ARRs actually aggregate the abnormal returns for all $\mathrm{N}$ firms to find the average abnormal return at each day t. The average abnormal return $\left(\mathrm{AAR}_{\mathrm{t}}\right)$ for each day in the event window is calculated as per the following equation:

$$
\operatorname{AAR}_{\mathrm{t}}=\frac{1}{\mathrm{~N}} \sum_{\mathrm{j}=1}^{\mathrm{N}} \mathrm{AR}_{\mathrm{jt}}
$$

where $\mathrm{N}$ is the number of firms.

The cumulative abnormal return (CAR) for a given security is the sum of daily ARs over the event window. Over an interval of two or more trading days beginning with day $\mathrm{T}_{1}$ and ending with day $\mathrm{T}_{2}$, the CAR is calculated as per the following equation:

$$
\mathrm{CAR}_{\mathrm{T}_{1} \mathrm{~T}_{2}}=\sum_{\mathrm{t}=\mathrm{T}_{1}}^{\mathrm{T}_{2}} \mathrm{AR}_{\mathrm{jt}}
$$

The cumulative average abnormal return (CAAR) for an interval of two or more trading days beginning with day $\mathrm{T}_{1}$ and ending with day $\mathrm{T}_{2}$ in the event window is calculated as per the following equation:

$$
\mathrm{CAAR}_{\mathrm{T}_{1} \mathrm{~T}_{2}}=\frac{1}{\mathrm{~N}} \sum_{\mathrm{j}=1}^{\mathrm{N}} \sum_{\mathrm{t}=\mathrm{T}_{1}}^{\mathrm{T}_{2}} \mathrm{AR}_{\mathrm{jt}}
$$

where $\mathrm{N}$ is the number of firms.

In order to assess the statistical significance of AARs, cross sectional $t$ test has been applied here. To get the cross sectional $t$ statistics of AAR at time $t$, following equation have tested here.

$$
\mathrm{t}_{\mathrm{AAR}_{\mathrm{t}}}=\mathrm{AAR}_{\mathrm{t}} /\left(\sigma\left(\mathrm{AR}_{\mathrm{jt}}\right) / \sqrt{\mathrm{n}}\right)
$$

So as to indicate the significance of impact of a merger event, CAAR need to be statistically tested. Event study is used to specify the performance of stock price over the time period by the analyzing CAAR for the sample of events and that should be significantly not equal to zero. If the CAAR is statistically significant and are greater than zero, it indicates the positive respond on the stock price after announcement of merger. On the contrary, if the CAAR is statistically significant and less than zero, it indicates the negative respond on the stock price due to the merger announcement. Thus, in order to test the statistical significance of CAAR, cross sectional $t$ test have been applied here. To get the cross sectional $t$ statistics of CAAR across the sample, following equation have tested here.

$$
\mathrm{t}_{\mathrm{CAAR}}=\mathrm{CAAR} /\left(\sigma\left(\mathrm{CAR}_{\mathrm{j}}\right) / \sqrt{\mathrm{n}}\right)
$$

In this study, CAARs over varying windows, namely, $(-20,+20),(-10,+10),(-5,+5),(-2,+2),(-1,+1), \quad(-$ $20,-2),(+2,+20),(-5,0),(0,+5),(-1,0),(0,+1)$, etc. have been computed to catch the leakage effect.

To achieve second specific objective of the study and to test the research hypothesis II, paired t test have been used. Here data have been divided into two categories i.e., before merger and after merger. In before merger, average abnormal return data from day -20 to day -1 has been used and in after merger, average abnormal return data from day +1 to day +20 have been used.

\section{MAJOR FINDINGS OF THE STUDY 6.1 Analysis of the magnitude of abnormal returns earned by shareholders owing to the merger announcement}

Table 1 depicts the statistical results of the event study conducted to measure the changes that occurred in shareholders wealth of the acquiring firm in short run around the announcement of merger event by identifying the responses of the share prices of acquiring bank. It portrays the AAR, corresponding t-statistic values, level of significance and also CAARs for each day in the event window along with corresponding t-statistic values and level of significance. Moreover, Figures 1 and 2 graphically represent the value of AARs and CAARs corresponding to each day of the event window. 


\section{EPRA International Journal of Research and Development (IJRD)}

Volume: 5 | Issue: 8 | August 2020

- Peer Reviewed Journal

Table 1: Cross-Sectional AARs and CAARs with test statistics on and around merger announcements

\begin{tabular}{|c|c|c|c|c|c|c|}
\hline Day & AAR (\%) & t-statistic & p-value & CAAR (\%) & t-statistic & p-value \\
\hline-20 & 1.53 & 1.342 & 0.272 & 1.53 & 1.342 & 0.272 \\
\hline-19 & 0.39 & 0.464 & 0.674 & 1.93 & $2.413^{*}$ & 0.095 \\
\hline-18 & 3.27 & 1.786 & 0.172 & 5.19 & $3.127^{*}$ & 0.052 \\
\hline-17 & -4.71 & $-5.279^{* *}$ & 0.013 & 0.48 & 0.331 & 0.762 \\
\hline-16 & -5.45 & $-10.409 * * *$ & 0.002 & -4.97 & $-3.423^{* *}$ & 0.042 \\
\hline-15 & -2.41 & $-5.436^{* *}$ & 0.012 & $\begin{array}{l}-7.38 \\
\end{array}$ & $-4.172^{* *}$ & 0.025 \\
\hline-14 & -12.95 & $-11.870^{* * *}$ & 0.001 & -20.33 & $-7.147^{* * *}$ & 0.006 \\
\hline-13 & 7.60 & $5.464^{* *}$ & 0.012 & -12.73 & $-3.878^{* *}$ & 0.030 \\
\hline-12 & -5.10 & $-7.008^{* * *}$ & 0.006 & -17.83 & $-4.538^{* *}$ & 0.020 \\
\hline-11 & -0.44 & -0.824 & 0.470 & -18.27 & $-4.513^{* *}$ & 0.020 \\
\hline-10 & -1.09 & -0.582 & 0.601 & -19.36 & $-3.326^{* *}$ & 0.045 \\
\hline-9 & 1.88 & 1.587 & 0.211 & -17.48 & $-3.194^{* *}$ & 0.050 \\
\hline-8 & 1.92 & 1.022 & 0.382 & -15.56 & $-2.728^{*}$ & 0.072 \\
\hline-7 & -13.37 & $-3.862^{* *}$ & 0.031 & -28.93 & $-3.195^{* *}$ & 0.050 \\
\hline-6 & 2.67 & 1.098 & 0.353 & -26.26 & $-2.832^{*}$ & 0.066 \\
\hline-5 & -0.25 & -0.118 & 0.914 & -26.51 & $-3.674^{* *}$ & 0.035 \\
\hline-4 & 3.06 & 1.676 & 0.192 & -23.45 & $-3.912^{* *}$ & 0.030 \\
\hline-3 & 1.81 & 2.209 & 0.114 & -21.64 & $-3.665^{* *}$ & 0.035 \\
\hline-2 & -2.48 & -2.285 & 0.106 & -24.12 & $-3.535^{* *}$ & 0.038 \\
\hline-1 & 1.71 & 1.435 & 0.247 & -22.41 & $-3.730 * *$ & 0.034 \\
\hline 0 & -0.41 & -0.238 & 0.828 & -22.82 & $-4.435^{* *}$ & 0.021 \\
\hline+1 & -1.63 & -0.833 & 0.466 & -24.45 & $-4.318^{* *}$ & 0.023 \\
\hline+2 & 2.43 & $5.760^{* *}$ & 0.010 & -22.02 & $-4.166^{* *}$ & 0.025 \\
\hline+3 & 1.47 & $3.550^{* *}$ & 0.038 & -20.56 & $-3.908^{* *}$ & 0.030 \\
\hline+4 & 2.89 & 2.288 & 0.106 & -17.66 & $-4.366^{* *}$ & 0.022 \\
\hline+5 & -1.97 & $-2.536^{*}$ & 0.085 & -19.63 & $-4.179 * *$ & 0.025 \\
\hline+6 & -0.11 & -0.119 & 0.913 & -19.75 & $-3.681^{* *}$ & 0.035 \\
\hline+7 & 0.05 & 0.102 & 0.925 & -19.69 & $-3.487^{* *}$ & 0.040 \\
\hline+8 & 0.75 & 1.199 & 0.317 & -18.95 & $-3.564^{* *}$ & 0.038 \\
\hline+9 & 6.77 & 2.171 & 0.118 & -12.17 & $-2.4628^{*}$ & 0.091 \\
\hline+10 & -6.17 & $-6.596^{* * *}$ & 0.007 & -18.35 & $-3.126^{*}$ & 0.052 \\
\hline+11 & -0.56 & -0.608 & 0.586 & -18.90 & $-3.104 *$ & 0.053 \\
\hline+12 & 1.57 & $2.888^{*}$ & 0.063 & -17.33 & $-2.854^{*}$ & 0.065 \\
\hline+13 & -2.72 & $-16.141^{* * *}$ & 0.001 & -20.05 & $-3.301^{* *}$ & 0.046 \\
\hline+14 & 1.20 & 2.135 & 0.122 & -18.85 & $-3.094^{* *}$ & 0.054 \\
\hline+15 & 2.20 & 1.289 & 0.288 & -16.65 & $-2.787^{*}$ & 0.069 \\
\hline+16 & 2.59 & $3.184^{* *}$ & 0.050 & -14.06 & $-2.642^{*}$ & 0.078 \\
\hline+17 & 0.81 & $3.160^{*}$ & 0.051 & -13.25 & $-2.465^{*}$ & 0.090 \\
\hline+18 & -6.86 & $-6.602^{* * *}$ & 0.007 & -20.12 & $-3.744^{* *}$ & 0.033 \\
\hline+19 & -1.85 & $-3.158^{*}$ & 0.051 & -21.96 & $-3.992^{* *}$ & 0.028 \\
\hline+20 & -0.02 & -0.016 & 0.988 & -21.98 & $-4.359 * *$ & 0.022 \\
\hline
\end{tabular}

Source: Own Computation

$*$ significance at $10 \%$ level, $* *$ significance at $5 \%$ level, $* * *$ significance at $1 \%$ level

Table 1 shows that during pre-tie up period, the ARRs are positive for 10 days, while they are also negative for 10 days. Out of total 10 positive ARR values, ARR of day 13 before announcement is significant at 0.05 level. Negative ARRs of 10 days shows six significant values. The AAR on the 


\section{EPRA International Journal of Research and Development (IJRD) \\ Volume: 5 | Issue: 8 | August 2020 \\ - Peer Reviewed Journal}

announcement day (0) is -0.41 per cent which is not significant. The negative and insignificant AARs on the announcement (day 0) indicate that the investors remark the announcement of merger to be unfavorable for them. However, the change of negative reaction to positive from day 2 after the tie up is noticed which indicates that although investors have shown negative reaction on and before the event but later a correction takes place quickly.

During post-tie up period, the ARRs are positive for 11 days, while they are also negative for 9 days.
Out of total 11 positive ARR values, ARR of 5 days are significant at various levels of significance. Negative ARRs of 9 days shows five significant values. Such findings lead to a conclusion that the null hypothesis of zero AARs, means no impact of merger on ARRs, is rejected for 17 days out of total 41 days event window. Table 1 has observed the highest positive ARR of 7.60 per cent on day 13 before announcement and the highest negative ARR of 13.37 per cent on day 7 before announcement of merger.

Figure 1: Average Abnormal Return during Event Window

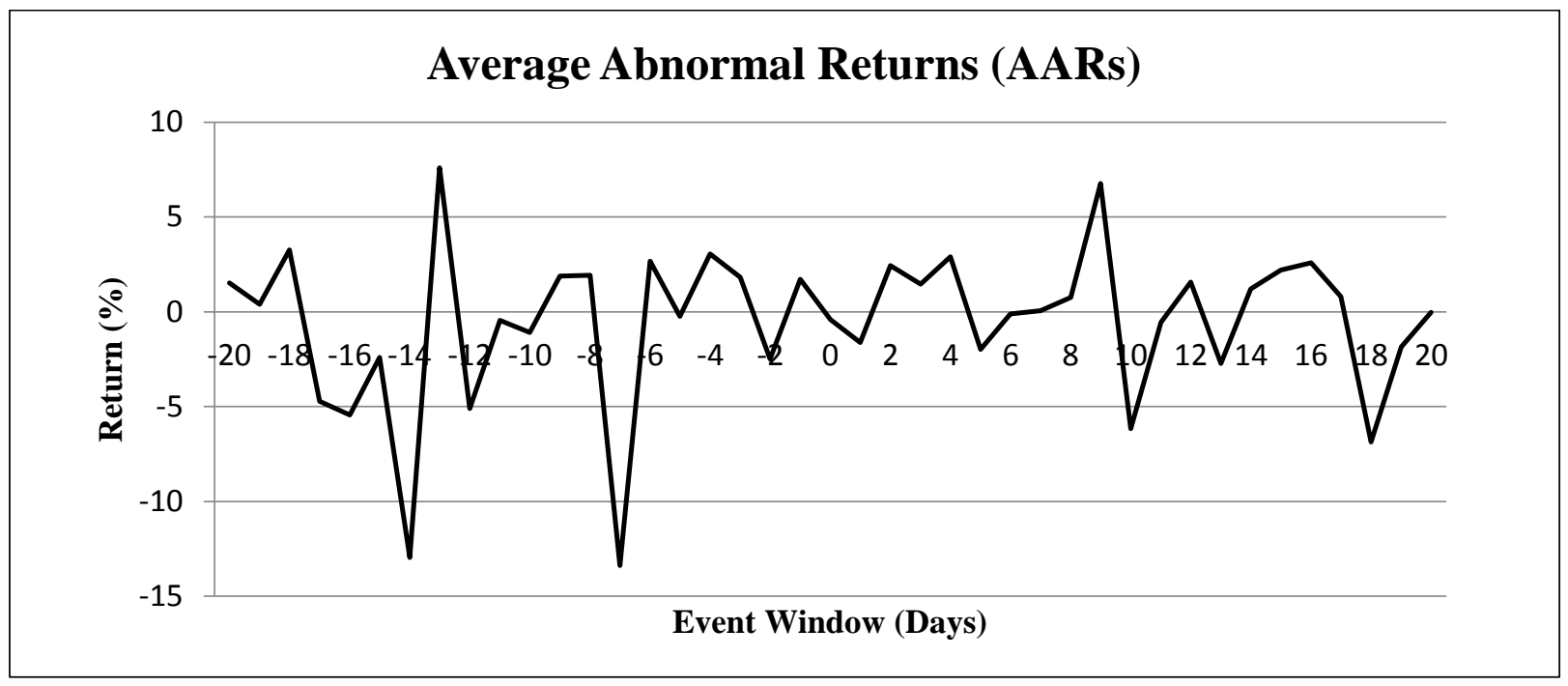

As seen in figure 1, after a negative move of stock price from day 17 to day 14 during pre-tie up, a positive move can be observed on day 13 before announcement. This positive move in the event window show a sign of insider trading which gives some participants the opportunity to make excess returns. Again after a negative AAR on the day of announcement, from day $+2(2.43 \%)$, the returns jumped up suddenly to day $+4(2.89 \%)$, then dropped down to day +5 and again start rising. The sharp move in the returns shows that the market responds to the information of merger. Ups and down in ARRs throughout the event window indicates that some market specific and industry specific factors are also there to affect the stock price movement besides the merger information.

The AARs are also cumulated over the event window to assess the net magnitude of the overall returns. Table 1 illustrates that during the pre- announcement window, the pattern of positive CAARs starts from day 20 before the announcement day and it last till day 17 before the announcement but after that CAAR starts becoming negative from 16th day in the pre-event window and observe a negative pattern till the last day of the event widow. The CAAR value of 16 th day in the pre-event window starts from -4.97 per cent and reaches to a peak of almost -28.93 per cent on day seven before the announcement and settles at 21.98 per cent on the last day of the event window. Except day -20 and day -17 , all other values of CAARs throughout the event window are noteworthy at various levels of significance. On the day of announcement the CAAR is -22.82 which is significant at 0.05 . Continuous negative CAARs from day -16 to last day of event window, as depicted in figure 2, are noticeable. After the initial respond to the merger information, finally investors have under-reacted to the event might be due to pandemic situation running throughout the 


\section{EPRA International Journal of Research and Development (IJRD)}

Volume: 5 | Issue: 8 | August 2020

- Peer Reviewed Journal

world. However, CAARs and their corresponding tstatistic with level of significance lead to a conclusion that the null hypothesis of zero CAARs, means no impact of merger on CARRs, is rejected for 39 days out of total 41 days event window.

Figure 2: Cumulative Average Abnormal Return during Event Window

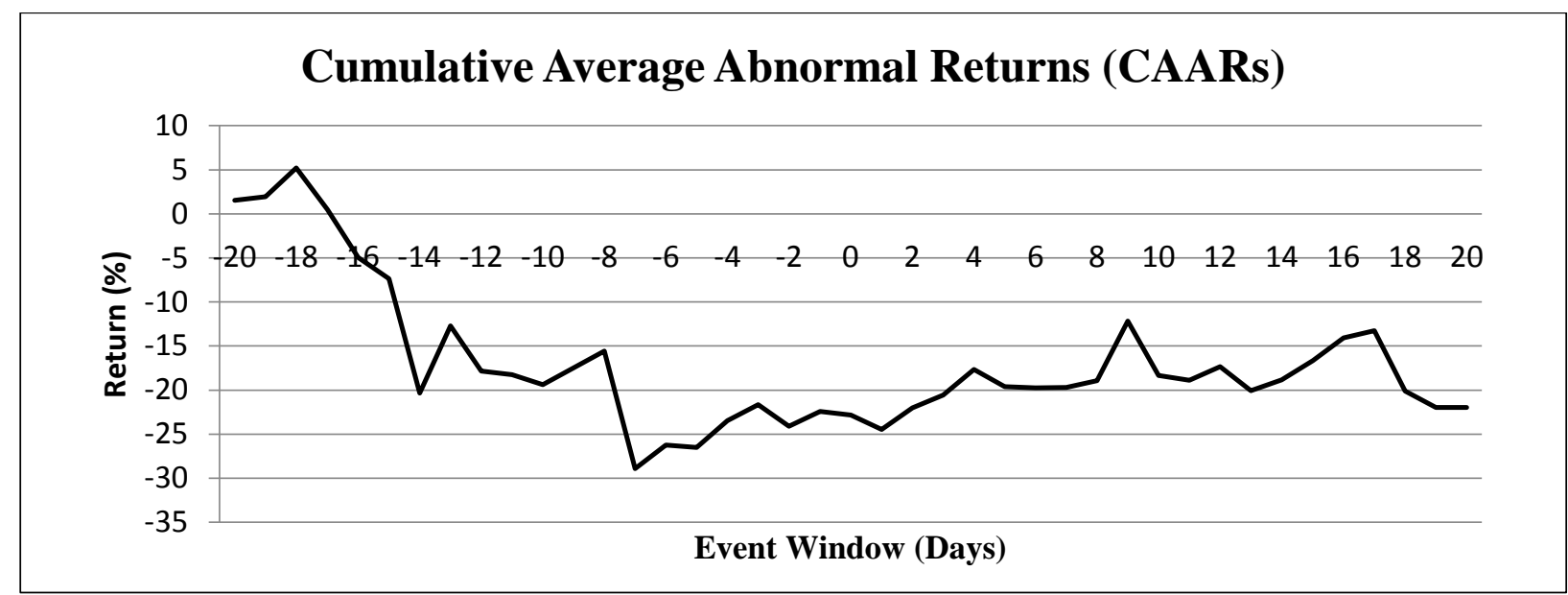

Likewise, CAARs over various size event windows are considered to place an opinion upon the important period from investment viewpoint. CAARs over different window size are tabulated in Table 2 . The CAAR computed for the event window $(-20$ to +20$)$ discloses the fact that for some of events, there is a negative AAR. On an average, the CAAR is $-21.98 \%$ and quite distant from zero which might be due to the reason of the event window being too long but the CAARs for this window is statistically significant at 0.05 levels. This is why the examination of CAAR is done by reducing the event window around the event day zero to $(-15$ to +15$)$. It is observed that, although some of the events still register negative CAR and CAAR decreased to $-11.08 \%$ which is statistically significant at 0.10 levels but still this figures register the same fact as described above. In order to get consistency with positive results further reductions of the event window to $(-10,+10),(-5$ to 5$),(-3$ to 3$),(-2$ to 2$)$ and ( -1 to 1$)$ have been done. We observed improvements in the level of CAAR obtained, $-0.33 \%$ for the (-1 to 1$)$ but not statistically significant.

Table 2: CAARs with test statistics for merger announcements across various event window

\begin{tabular}{|c|c|c|c|c|}
\hline Event Window & No. of Days & CAAR (\%) & t-statistic & p-value \\
\hline$(-20$ to +20$)$ & 41 & -21.98 & $-4.359^{* *}$ & 0.022 \\
\hline$(-19$ to +19$)$ & 39 & -23.50 & $-3.757^{* *}$ & 0.033 \\
\hline$(-18$ to +18$)$ & 37 & -22.04 & $-4.193^{* *}$ & 0.025 \\
\hline$(-17$ to +17$)$ & 35 & -18.45 & $-3.804^{* *}$ & 0.032 \\
\hline$(-16$ to +16$)$ & 33 & -14.54 & $-3.529^{* *}$ & 0.039 \\
\hline$(-15$ to +15$)$ & 31 & -11.68 & $-2.429^{*}$ & 0.093 \\
\hline$(-14$ to +14$)$ & 29 & -11.47 & $-2.459^{*}$ & 0.091 \\
\hline$(-13$ to +13$)$ & 27 & 0.28 & 0.067 & 0.951 \\
\hline$(-12$ to +12$)$ & 25 & -4.60 & -0.876 & 0.446 \\
\hline$(-11$ to +11$)$ & 23 & -1.07 & -0.228 & 0.834 \\
\hline$(-10$ to +10$)$ & 21 & -0.08 & -0.014 & 0.989 \\
\hline$(-9$ to +9$)$ & 19 & 7.19 & 1.192 & 0.319 \\
\hline$(-8$ to +8$)$ & 17 & -1.47 & -0.316 & 0.773 \\
\hline$(-7$ to +7$)$ & 15 & -4.14 & -0.922 & 0.425 \\
\hline
\end{tabular}




\section{EPRA International Journal of Research and Development (IJRD)}

Volume: 5 | Issue: 8 | August 2020

- Peer Reviewed Journal

\begin{tabular}{|c|c|c|c|c|}
\hline$(-6$ to +6$)$ & 13 & 9.18 & 1.517 & 0.226 \\
\hline$(-5$ to +5$)$ & 11 & 6.63 & 1.160 & 0.330 \\
\hline$(-4$ to +4$)$ & 9 & 8.84 & 1.950 & 0.146 \\
\hline$(-3$ to +3$)$ & 7 & 2.89 & 1.084 & 0.358 \\
\hline$(-2$ to +2$)$ & 5 & -0.38 & -0.140 & 0.897 \\
\hline$(-1$ to +1$)$ & 3 & -0.33 & -0.095 & 0.930 \\
\hline$(-20$ to -2$)$ & 19 & -24.12 & $-3.535^{* *}$ & 0.038 \\
\hline$(-5$ to 0$)$ & 6 & 3.44 & 0.551 & 0.620 \\
\hline$(-1$ to 0$)$ & 2 & 1.30 & 0.478 & 0.665 \\
\hline$(0$ to +1$)$ & 2 & -2.04 & -0.665 & 0.554 \\
\hline$(0$ to +5$)$ & 6 & 2.77 & 1.028 & 0.380 \\
\hline ( 2 to +20$)$ & 19 & 2.46 & 0.418 & 0.704 \\
\hline
\end{tabular}

Source: Own Computation

*significance at $10 \%$ level, $* *$ significance at $5 \%$ level, $* * *$ significance at $1 \%$ level

For the pre-announcement event windows $(-20$, $-2),(-5,0)$, and $(-1,0)$, the CAAR values are -24.12 per cent, 3.44 per cent and 1.30 per cent, respectively but on the CAAR of event windows $(-20,-2)$ is statistically significant at 0.05 levels. Moreover, the CAAR values of 2.67 per cent on day 6 before the announcement, -0.41 per cent on the announcement day, and -0.11 per cent on day 6 after the announcement indicate that an investor can gain a substantial CAAR of 9.18 per cent if the shares of the issuing company are purchased six day prior to the announcement day and sold six day after the announcement day. CAARs for event window $(-5,+5)$ and $(-4,+4)$ is 6.63 per cent and 8.84 per cent respectively which is quite impressive. For the post-announcement event windows $(+2,+20)$, $(0,+5)$, and $(0,+1)$, the CAAR values are 2.46 per cent,
2.47 per cent and -2.04 per cent, respectively but none of the CAARs are statistically significant.

\subsection{Comparative analysis of abnormal returns earned before and after the merger announcement}

To achieve second specific objective of the study and to test the research hypothesis II, paired t test have been opted. Here entire event window have categorised into pre- merger and post-merger and AARs data have been divided accordingly into two categories i.e., ARR before merger and ARR after merger. In before merger, average abnormal return data from day -20 to day -1 has been considered and in after merger, average abnormal return data from day +1 to day +20 have been used.

Table 3: Paired Samples Statistics for Average Abnormal Return around merger

\begin{tabular}{|cc|c|c|c|c|}
\hline & & Mean & N & Std. Deviation & Std. Error Mean \\
\hline \multirow{2}{*}{ Pair 1 } & ARR before Merger & -1.1203 & 20 & 5.1990 & 1.1625 \\
& AAR after Merger & 0.0417 & 20 & 3.0936 & 0.6917 \\
\hline
\end{tabular}

Source: Own Computation

Table 3 clearly indicates that mean of average abnormal return before merger is -1.1203 whereas mean of average abnormal return after merger is 0.0417 which certifies that greater return is available during post-merger. As greater return is associated with postmerger period, investors can obtain more returns if they invest in the stock during post-merger. Further, the standard deviation from the mean is lower in postmerger event which speaks us that there is low risk associated with average abnormal return in case of post-merger in comparison with pre- merger event.

Table 4: Paired Samples Correlations for Average Abnormal Return around merger

\begin{tabular}{|ll|c|c|c|}
\hline & N & Correlation & Sig. \\
\hline Pair 1 ARR before Merger \& AAR after Merger & 20 & -.141 & .553 \\
\hline
\end{tabular}


Table 4 demonstrates that there is negative weak correlation between the average abnormal return before and after the Merger.

Table 5 : Paired Samples Test for Average Abnormal Return around merger

\begin{tabular}{|c|c|c|c|c|c|c|c|c|}
\hline & \multicolumn{5}{|c|}{ Paired Differences } & \multirow{3}{*}{$\mathbf{t}$} & \multirow{3}{*}{ df } & \multirow{3}{*}{$\begin{array}{l}\text { Sig. (2- } \\
\text { tailed) }\end{array}$} \\
\hline & \multirow[t]{2}{*}{ Mean } & \multirow[t]{2}{*}{$\begin{array}{c}\text { Std. } \\
\text { Deviatio } \\
\mathbf{n}\end{array}$} & \multirow[t]{2}{*}{$\begin{array}{l}\text { Std. } \\
\text { Error } \\
\text { Mean }\end{array}$} & \multicolumn{2}{|c|}{$\begin{array}{c}95 \% \text { Confidence } \\
\text { Interval of the } \\
\text { Difference }\end{array}$} & & & \\
\hline & & & & Lower & Upper & & & \\
\hline $\begin{array}{cc}\text { Pair } 1 & \begin{array}{c}\text { ARR before Merger \& } \\
\text { AAR after Merger }\end{array}\end{array}$ & -1.1619 & 6.4137 & 1.4341 & -4.1637 & 1.8398 & -.810 & 19 & .428 \\
\hline
\end{tabular}

Source: Own Computation

Table 5 portrays the paired sample test for Average Abnormal Return. While testing the paired $t$ test, significance level of 0.05 is opted and the two tailed test is chosen in this case. The significance value which is more than the 0.05 indicates non rejection of the hypothesis that states that there is no significant difference in average abnormal returns before and after merger. Thus, it can be opined that merger makes no significant difference in average abnormal return.

\section{CONCLUSION}

Pattern and magnitude of stock return normally provide an idea regarding the attitude of investors on their perception of an unexpected event going to be happened in the market. A positive pattern of return indicates that investors have positively reacted to the information of the merger event while negative pattern indicate the negative-reaction of investors regarding the announcement of the event. The announcement of Merger is usually professed as optimistic favorable information for the investors. We have empirically scanned the attitude of investors and their perception towards the announcement of merger. The study confirms that the shareholders of acquirer banks have negatively reacted about the merger information before the event but after the announcement a positive sentiment of investors towards the information have been observed from day 2. Study reveals that investors are not able to earn the significant excess return on the day of announcement because of their soothed nature towards the information of merger. But from day +2 $(2.43 \%)$, the AARs jumped up suddenly to day +4 $(2.89 \%)$, then dropped down to day +5 and again start rising. Again from day +10 it starts falling. This prompt swing in the returns shows that the market responding significantly not only to the information of merger rather there are some other market specific and industry specific factors which are playing a direct or indirect role in affecting the stock price movement throughout the event window. CAARs figures also point toward the positive pattern of returns in the beginning of the event window but rapidly it becomes negative from day -16 to the last day of window that might be due to pandemic situation running throughout the world. However, the study of combined event window shows that an investor can earn significant returns if he purchases the shares within six days before the effective date of merger and sells the shares six days after the announcement. An investor can also earn substantial return if the shares of the acquiring company are purchased four days prior to the announcement day and sold four days after the announcement day.

\section{REFERENCES}

1. Anand, M., and Singh, J. (2018), "Impact of Merger Announcements on Shareholders Wealth: Evidence from Indian Private Sector Banks", VIKALPA, Vol. 33, pp. 35-54.

2. Chaitra, R., Manjunath, B., and Rehaman, M. (2019), "An Analysis of pre and post-Merger of Indian Banks: An Event Analysis approach", International Journal for Research in Engineering Application \& Management, pp. 172-178.

3. Kalaichelvan, K. (2011), "Efficacy of merger and acquisition in Indian Banking Industry”, Ph.D Thesis submitted in Pondicherry University, August 2011.

4. Kalsie, A., and Arora, A. (2018), "Analysis of Merger and Acquisition Deals of Major Indian Banks: An Event Based Study", Effulgence, Vol. 16, pp. $82-120$.

5. Kumara, R.N., and Reddy, B. N. (2019), "A study on the impact of Pre and Post Bank Merger Announcement on Stock Price Movement", 


\section{EPRA International Journal of Research and Development (IJRD) \\ Volume: 5 | Issue: 8 | August 2020

International Journal of Research and Analytical Reviews, Vol. 6, pp. 955-1001.

6. Kumar, R. B., Gera, S., and Saha, S. (2016), "Wealth Creation in the Largest Banking Mergers - An Empirical Analysis", Asian Economic and Financial Review, Vol. 6(4), pp. $206-217$.

7. Narwal, P.K., and Pathneja, S. (2013), “Stock Market Reactions to Mergers Announcement: A Study of Voluntary and Compulsory Mergers in Indian Banking Sector", International Journal of Money, Banking and Finance, Vol. 2, pp. 24-29.

8. Patel, R., and Shah, D. (2016), "Mergers and Acquisitions : A Pre-Post Risk Return Analysis for the Indian Banking Sector", Journal of Applied Finance \& Banking, Vol. 6, pp. 99-113

9. Samontaray, P.D., and Choudhary, K. (2013), "Merger and Acquisition in Indian Banking Industry: An Event Study Approach", Australian Journal of Basic and Applied Sciences, Vol. 7(11), pp. 252-262.

10. Shah, A., and Deo, M. (2013), "Bank Mergers and Shareholder Value Creation in India”, International Journal of Business and Society, Vol. 14, pp. 245-264.

11. Yadav, Y. (2017), "Impact of Mergers and Acquisitions on the Performance of the Indian Bank's Share Price: An Event Study Approach", Australian Journal of Management, pp. 1-12

12. https://www1.nseindia.com/products/content/equities/ equities/eq_security.htm 